\title{
Migration, Relief \& Rehabilitation and Social-Living Condition of Kashmiri Pandit Migrants of Camp and Non-Camp Areas in Jammu District.
}

\author{
Som Raj, Dr.Sunita Sharma and Manjeet Singh
}

\begin{abstract}
The disturbed conditions existing due to onset of militancy in the Kashmir Valley since 1990, led to mass exodus of the Kashmiri Pandits from the valley of Kashmir to Jammu and other parts of the country. A number of measures by government have been taken over the year by way of financially assistance/relief and other initiatives to provide support to the affected families within a broad policy framework that those who have migrated will eventually return to the valley. Government has been providing relief to those displace families of camp and non-camp area in Jammu district who have no source of income after migration. This study is an attempt to analyse the social-living conditions of Kashmiri migrants of camp and non-camp area in Jammu district.
\end{abstract}

Keywords: Kashmiri Pandits, Migration, Militancy, Relief \& Rehabilitation, Social-living conditions.

\section{Introduction}

The history of mankind is the history of human movement; mostly voluntary, but as the world become more populated and as open spaces began to shrink, these movements increasingly became involuntary. Inhabitants or peoples have a different form of insecurity in front of them whether stemming from violence or from lack of access to a decent life or as a result of economic deprivation are leaving their earths and homes in search of safety and better opportunities elsewhere. Masses are everywhere in plight. There are various reasons for compelling their movements. A movement of inhabitants from their origin of place to another for the purpose of setting down (temporary or permanent etc.) is generally known as migration.

Migration is a permanent or temporary change of the citizens typically recognised as some type of administrative boundary occurring across region or country. Unlike the singularly occurring demographic events of birth and death a person may migrate many times, for varied durations and beyond numerous territorial boarders. (Wood,1994).

Internal migration means movement from one region of a given nation to another region within the nation. Like international resettlement this too can be voluntary or forced depending on the prevailing circumstances at the place of departure (Agozino, 2000). The nature of migration is broadly classified in terms of type of choice (Voluntary or involuntary) or geographical territory (International or internal), Rural to rural, rural to urban, urban to rural, urban to urban. Involuntary or voluntary forced migration is caused due to a variety of reasons related to poverty, manmade or environmental disasters that pose a severe threat to life and do not allow the individual to remain at his place of residence any longer living no other option but to leave.

The structural causes of involuntary internal migration are identified as politically motivated brutality, ethnic wars, which pose dire threat to life instigating the move to resettle away from present residence but not out of the national boundary. Such conflicts of a nation's state are rather different from wars between nations they occur along the lines of ethnicity, religions or communal or even linguistic differences and play out with such fragmented complexity that it is difficult to resolve them unambiguously (Cohen and Dong, 1998).

The migration of mass population within their own countries has become a serious problem worldwide because it affects the people, their livelihood and also results in cultural alienation and identity crisis. It is one of the vital issues faced by human civilization now-a-days. There are number of peoples who have been migrated due to violence, natural disasters internal conflicts and communal violence.

The conflict and war like situation between India and Pakistan have been responsible for displacement along the borders and other places as well. On the other hand, India is suffering from terrorism problems, which is also responsible for displacement of persons from their respective places. It creates abnormal situation in which persons are forced to leave their natural habits within India, the different states are victims of terrorism thereby the movement of peoples has also become inevitable. The Jammu and Kashmir state is classic case in point.

The state of Jammu and Kashmir has experienced the various types of migration which has taken place due to number of reasons. Sometime war and war like situation between India and Pakistan resulting into displacement in the border areas of the state, whereas in other time migration or displacement has been due to 
terrorism that existed in the state. The growth of militancy in the Kashmir valley and its adjoining areas since 1988 led to politico-ethnic divide between the two major communities inhabiting the valley, due to which many Kashmiri families living in valley had been forced to leave their natural places and leave the valley. While majority of them happened to be Hindu, there were Muslims and Sikhs among those who were displaced by conflict. It is because of conflict migration in Jammu and Kashmir State has taken place.

The early 1990's period, witnessed selective killing of prominent personalities supporting Indian rule in Kashmir valley, mass rallies chanting anti-Indian and Islamic slogans denouncing of symbols of Indian nationalism and attempts at its Islamisation. During the period of 1990s, the state apparatus has failed to control militancy conflicts and provide security to minority of Kashmiri Pandits who had been comfortable with Kashmir's accession to the Indian Union cannot identify with the Azadi movement led by Kashmiri Muslims challenging Indian sovereignty. It was the time of bad circumstances, in which the Kashmiri Pandits migration has been taken place from the valley of Kashmir in the J\&K state and to other parts of the country. Thousands of Kashmiri Pandits left the Kashmir valley within a month. Even after two decades, the question of pandit's migration is very much vibrant in the discussion on contemporary self-determination (Khalid Wasim2008).

In the early 1990s migration took place from the valley of Kashmir-murder inhuman, loot and practices like branding with hot iron, lynching, burning alive, etc. by terrorists compelled Kashmiri Pandits families to move out of their motherland, within the short span time of one week to fornight stated by migration was the only way out for them to save their kith \& kin which changed their life style (Zutshi, 2003). These developments have led to forced migration for Kashmir.

\section{Methodology}

Research Methodology:The present study entitled migration, relief \& rehabilitation and social-living condition of Kashmiri migrants of camp and non-camp area in Jammu district is based on primary and secondary sources. Secondary information and data has been collected through books, Journals and various reports etc. Primary data has been collected through comprehensive questionnaire.

Selection of the area: - The universe for conducting the present study has been selected through purposive sampling technique i.e. camp area of Nagrota and non-camp area of Durga Nagar because of high concentration of migrant Kashmiri pandits in these areas.

Selection of the households: - A sample of 35 households each from camp and non-camp areas in Jammu district has been selected randomly.

Methods of Enquiry and collection of data: - The enquiry has been conducted through the survey method. Data has been collected through personal interview method with the respondents in a well-structured questionnaire.

Analysis of data: - After the collection of the data it has been tabulated and analysed with simple statistical tools such as percentage.

Relief and rehabilitation of Kashmiri migrants: The Relief Organisation is headed by Relief and Rehabilitation Commissioner and is working under the administrative control of the Revenue Department. Terrorist violence/militancy in Jammu \& Kashmir, particularly in its early phase, had led to large scale forced migration of members of the Kashmiri Pandits community from the Kashmir Valley. There are number of measures have been taken by government over the year to tackle the problems of Kashmiri migrants by way of providing financially support/relief to them. Government has been providing financially support/ relief to those migrants who have no source of income after migration at their residing place. Those who were government employees prior to migration were adjusted in their respective departments, in Jammu, Delhi and other parts of the country. The total amount of relief given is for up to four family members only. If the number of family members is more than four, even then the amount is restricted to Rs. 4000. But in case the number of members is less than four i.e. 3 or 2 the amount is curtailed accordingly, like Rs. 3000 for family of two members. In terms of ration provided to families, if a family have a newly born baby then it is provided with an extra quantity of sugar ( $250 \mathrm{Gms}$ per month) for next 4 years.

According to the Ministry of Home AffairsAnnual Report of 2002-03, Government employees and pensioners numbering 21824 were not entitled for relief. Apart from this, the relief package does not take into consideration the construction and maintenance of camps and the expenditures on related physical and social infrastructure including toilets, roads, shops, water, electricity, hospital, education and communications.

With a view to improving the living conditions of the families living in camp in Jammu region, the Prime Minister of India, during his visit to J\&K in November, 2004 announced construction of 5242 two-room tenements at an estimated cost of Rs. 345 crore for Kashmiri Migrants staying presently in one room tenements in camp areas in Jammu provision. Construction of 1024 flats taken up at Purkhoo, Muthi and Nagrota in Jammu has been completed and allotted. Therefore, in order to call the Prime Minister of India, this package has been announced especially for increase the living rooms capacity in camp areas in Jammu District. Construction 
for remaining 4218 flats has been taken up at Jagati near Nagrota, which is being developed as township with all infrastructure facilities. This construction work was completed by October 2010 in Jammu Division.

\section{Cash And Ration Relief To Kashmiri Migrants With Effect From 2012.}

Cash and ration relief have been provided by the government of India and its limit have been changed with effect from 1st July, 2012, the rate of cash relief was given to Kashmiri Migrants at Jammu has been enhanced from the existing rate of Rs. 1250 per head per month, subject to a ceiling of Rs. 5000 per month per family of four or more members to Rs. 1650 per head per month, subject to a ceiling of Rs.6600 per month per family of four or more members. Kashmiri Migrants at Jammu are also being provided dry ration. Its detail given below:-

(A) Ration: $\quad 9 \mathrm{Kg}$ rice per soul per month.

$2 \mathrm{Kg}$ Atta per soul per month.

$1 \mathrm{Kg}$ Sugar per family per month.

Financial assistance in terms of relief provided by the government of India to Kashmiri migrants.

Table 4.2: Relief in cash to Kashmiri migrants since 1990 to till 2013-14.

\begin{tabular}{|l|l|c|}
\hline S. No. & \multicolumn{1}{|c|}{ Year } & Amount (per family, in Rs) \\
\hline 1 & $1 / 90$ to $4 / 90$ & 500 \\
\hline 2 & $5 / 90$ to $4 / 94$ & 1000 \\
\hline 3 & $5 / 94$ to $5 / 96$ & 1500 \\
\hline 4 & $6 / 96$ to $3 / 99$ & 1800 \\
\hline 5 & $4 / 99$ to $5 / 03$ & 2400 \\
\hline 6 & $6 / 03$ to $6 / 06$ & 3000 \\
\hline 7 & $7 / 06$ onwards & 4000 \\
\hline 8 & March 2010 & 5000 (1000 per person subject to 8 a ceiling of 5000 per family). \\
\hline 9 & $2013-14$ & 6600 (1650 per souls up to four family members) \\
\hline
\end{tabular}

Source: Survey Data

The Government of Jammu and Kashmir, the Government of the National Capital Territory of Delhi and the governments of other States and Union Territories where Kashmiri Pandit migrants are living have provided the migrants with food rations and cash relief (Source: The Tribune, 4 April 2010). Construction of more than 5000 two-room tenements for Kashmiri Pandit IDPs were staying in one-room shelters in camps in Jammu, this plan was completed by December 2010: (source: India Today, 5 June 2010.)

More than 5000 sets of two-room tenements have been completed and allocated to Kashmiri pandit migrants but a lot needs to be done on this front because those who are living in one room tenement is pathetic.

The Kashmiri migrants are not satisfied with the provisions of relief from Government implemented polices; because according to them, it is not sufficient to fulfil the basic needs of the family members. Food materials and accommodation facilities are very poor, particularly in camps areas. (Data collected through the interactions from Kashmiri pandits migrants in camp and non-camp area in Jammu District 2013-14).

\section{Social And Living Conditions Of Camp And Non-Camp Kashmiri Migrants}

Socio and living conditions of a population is an important indicator of the well-being of a community and can be assessed by studying the indicators such as demography profile, civic amenities, literacy rate, housing conditions and civic amenities. An attempt has been made in this chapter to investigate the socio-living conditions of the Kashmiri pandit migrants in camp and non-camp areas on the basis of the above given indicators.

\section{Demography Profile of the Households}

\section{Table No. 1.1}

Demography Profile of the Households

\begin{tabular}{|l|l|l|l|l|l|l|l|}
\hline \multirow{2}{*}{\begin{tabular}{c} 
Age $\begin{array}{c}\text { Camp } \\
\text { (in yrs.) }\end{array}$ \\
\hline Up to 4
\end{tabular}} & F & M & Total & F & M & Total & Grand Total \\
\hline $4-8$ & $4(3.12)$ & $2(1.56)$ & $6(4.68)$ & & $3(2.38)$ & $3(2.38)$ & $9(3.54)$ \\
\hline $8-12$ & $5(3.90)$ & $7(5.46)$ & $12(9.37)$ & $3(2.38)$ & $5(3.96)$ & $8(6.34)$ & $20(7.87)$ \\
\hline $12-16$ & $4(3.12)$ & $8(6.25)$ & $12(9.37)$ & $12(9.52)$ & $9(7.14)$ & $21(16.66)$ & $33(12.99)$ \\
\hline $16-35$ & $12(9.37)$ & $18(14.06)$ & $30(23.34)$ & $16(12.69)$ & $14(11.11)$ & $30(23.80)$ & $60(23.62)$ \\
\hline $35-60$ & $16(12.5)$ & $18(14.06)$ & $34(26.56)$ & $21(16.66)$ & $17(13.49)$ & $38(30.15)$ & $72(28.34)$ \\
\hline 60 above & $9(7.03)$ & $13(10.15)$ & $22(17.18)$ & $11(8.73)$ & $8(6.34)$ & $19(15.07)$ & $41(16.14)$ \\
\hline Total & $5(3.90)$ & $7(5.46)$ & $12(9.37)$ & $4(3.17)$ & $3(2.38)$ & $7(5.55)$ & $19(7.48)$ \\
\hline
\end{tabular}


Source: Survey Data

(Figure within brackets show the percentage with respect to total)

Table 1.1 shows the demographic profile of the households. 70 households under study have a composition of 254 members falling in different age groups. Out of $254,3.54$ per cent are in the age group of up to 4 years, 7.87 per cent in 4-8 years, 12.99 per cent in 8-12 years, 23.62 per cent in 12-16 years, 28.34 per cent in 16-35 years, 16.14 per cent in 35-60 years and 7.48 per cent in 60 and above age group. Out of 254, 48.03 per cent are female and 51.96 per cent are male.

In camp area out of total 42.96 per cent are female and 57.03 are male whereas in non-camp area 53.17 per cent are female and 46.82 per cent are male. So the sex composition is better in non-camp area. In Camp area out of total 4.68 per cent, 9.37 per cent each, 23.34 per cent, 26.56 per cent, 17.18 per cent and 9.37 per cent are in the age group of up to $4,4-8,8-12,12-16,16-35,35-60$ and 60 and above year's age group. Out of total female in camp area, majority i.e 12.5 per cent is in the age group of 16-35 and least 3.12 per cent each up to 4 years and 8 years. Out of total males in camp majority i.e 26-56 per cent are in the age group of 16-35 years and least 4.68 per cent are up to 4 years. In non-camp area out of total females 2.38 per cent, 9.52 per cent, 12.69 per cent, 16.66 per cent, 8.73 per cent and 3.17 per cent and of total males, 2.38, 3.96, 7.14, 11.11, 13.49, 6.34 and 2.38 per cent are in the age group of up to 4 years of age, 4-8, 8-12, 12-16, 16-35, 35-60 and above age group. No female is found in the age group of up to 4 years of age. In non-camp area also among females, majority 16.66 per cent are in the age group of 16-35 and least 2.38 per cent in 4-8 years of age. Among males, majority i.e 30.15 per cent is in the age group of 16-35 and only 2.35 per cent were found in the age group of up to 4 years of age.

\section{Educational Profile of the Head of the Households}

Table. 1.2

Educational Profile of the Head of the Households

\begin{tabular}{|l|l|l|l|}
\hline Level of education & Camp & Non-camp & Grand Total \\
\hline Up to middle & $2(5.71)$ & $3(8.57)$ & $5(7.14)$ \\
\hline Matric & $9(25.71)$ & $11(31.42)$ & $20(28.57)$ \\
\hline Higher Secondary & $11(31.42)$ & $9(25.71)$ & $20(28.57)$ \\
\hline Graduate & $3(8.57)$ & $2(5.71)$ & $5(7.14)$ \\
\hline Post-graduate & $1(2.85)$ & $3(8.57)$ & $4(5.71)$ \\
\hline Total & $26(74.28)$ & $28(80)$ & $54(77.14)$ \\
\hline
\end{tabular}

Source: Survey Data

(Figure within brackets show the percentage rate with respect to total respondents)

Out of total 22.85 per cent head of the households in the study area are illiterate. in camp area 25.72 per cent of the head of the households are illiterate and in non-camp area 20 per cent of the head of the households are illiterate and 5.57 per cent are the new entrance in the pre- nursery schools. Table. 1.2 shows the educational profile of the head of the households. In the study area a total of 77.14 per cent of the head of the households are literate of which 7.14 per cent head ,have education qualification up to middle level, 28.57 per cent each up to matric \& higher secondary level, 7.14 and 5.71 per cent have education qualification up to Graduate and postgraduate level. In camp area out of total literate 5.71 per cent of the head are educated up to middle, 25.71 per cent up to matric, 31.42 per cent up to Hr. secondary, 8.57 per cent and 2.85 per cent of the head of the households up to graduate and post- graduate level. In Non-camp area out of total 80 per cent of the head of the households are literate with different levels of education level. Out of these, $8.57 \mathrm{per}$ cent have education up to middle, 31.42 per cent up to matric, 25.71 per cent up to higher secondary, 5.71 per cent up to graduate and 8.57 per cent of the heads of the households have education up to post-graduate level. In non-camp area the heads of the households have higher level of education than in camp area.

\section{Educational Profile Of The Members Of The Households}

Educational profiles of the family members has been shown in table No.1.3 
Migration, Relief \& Rehabilitation and Social-Living Condition of Kashmiri Pandit Migrants of

Table.1.3. Educational Profile of the Members of the Households

\begin{tabular}{|c|c|c|c|c|c|c|c|}
\hline \multirow[t]{2}{*}{ Level of Education } & \multicolumn{3}{|c|}{$\begin{array}{c}\text { Camp } \\
\text { (Nagrota) }\end{array}$} & \multicolumn{3}{|c|}{$\begin{array}{l}\text { Non-Camp } \\
\text { (Durga Nagar) }\end{array}$} & \multirow[t]{2}{*}{ Grand Total } \\
\hline & Male & Female & Total & Male & Female & Total & \\
\hline Up to Middle & $7(6.08)$ & $4(3.47)$ & $11(9.56)$ & $9(7.56)$ & $7(5.88)$ & $16(13.44)$ & $27(11.53)$ \\
\hline Matric & $17(14.78)$ & $16(13.91)$ & $33(28.69)$ & $16(13.44)$ & $19(15.96)$ & $35(29.41)$ & $68(29.05)$ \\
\hline Higher Secondary & $20(17.39)$ & $12(10.43)$ & $32(27.32)$ & $17(14.28)$ & $16(13.44)$ & $33(27.73)$ & $65(27.77)$ \\
\hline Graduate & $11(9.56)$ & $12(10.43)$ & $23(20)$ & $11(9.24)$ & $7(5.88)$ & $18(15.12)$ & $41(17.52)$ \\
\hline Post Graduate & $4(3.47)$ & $8(6.95)$ & $12(10.43)$ & $4(3.36)$ & $6(5.04)$ & $10(8.40)$ & $22(9.40)$ \\
\hline Professional & $0(0)$ & $0(0)$ & $0(0)$ & $4(3.36)$ & $3(2.52)$ & $7(5.88)$ & $7(2.99)$ \\
\hline Others & $4(3.47)$ & $0(0)$ & $4(3.47)$ & $0(0)$ & $0(0)$ & $0(0)$ & $4(1.70)$ \\
\hline Total & $63(54.78)$ & $52(45.21)$ & $115(100)$ & $61(51.26)$ & $58(48.78)$ & $119(100)$ & $234(100)$ \\
\hline
\end{tabular}

Source: Survey data

(Figure within brackets show the percentage rate with respect to total respondents)

Table 1.3, show the educational profile of the members of the households under study in Jammu district.

Out of total literate 234 family members of these 70 households, 11.53, 29.05, 27.77, 17.52, 9.40, 2.99 and 1.70 per cent were with various levels of education. In camp area 115 family members of the households under study are literate, with 54.78 per cent of males and 45.21 per cent of females with different levels of education .Majority of males i.e 17.39 per cent are educated up to higher secondary level and of females i.e 13.91 per cent up to matric level.

In non-camp area 119 family members of the households under study are literate with 51.26 per cent of males and 48.78 per cent of females with different levels of education. Majority of males and females are educated up to matric level with least having professional education among both males and females.

Thus in non-camp area literacy level is better than in camp area.

\section{Nature of family of the households}

\section{Table.1.4}

Nature of family

\begin{tabular}{|l|l|l|ll|}
\hline Grand Total & Family & $\begin{array}{l}\text { Camp } \\
\text { (Nagrota) }\end{array}$ & $\begin{array}{l}\text { Non-Camp } \\
\text { (Durga Nagar) }\end{array}$ \\
\hline $63(90)$ & Nuclear family & $35(100)$ & 28 & $(80)$ \\
\hline $7(10)$ & Joint family & $0(0)$ & 7 & $(20)$ \\
\hline $70(100)$ & Total & $35(100)$ & 35 & $(100)$ \\
\hline
\end{tabular}

Source: Survey data

(Figure within brackets shows the percentage rate of households)

Table 1.4, shows the nature of family, majority of the respondents i.e., 90 per cent in the study area have nuclear families whereas only 10 per cent are living with joint families. In camp area (Nagrota), 100 per cent of the households have nuclear family, whereas, in non-camp (Durga Nagar area) 80 per cent households have nuclear families and 20 per cent had joint family. Nuclear family is more prevalent in camps because of their economic and social compulsions than in non-camp area. Poor living space that is single room accommodation, relief known as (chandi) in Kashmiri and other benefits and incentives are the reasons for nuclear families in camp area.

The following figure shows the nature of family in camp and non-camp area.

\section{Nature of family}

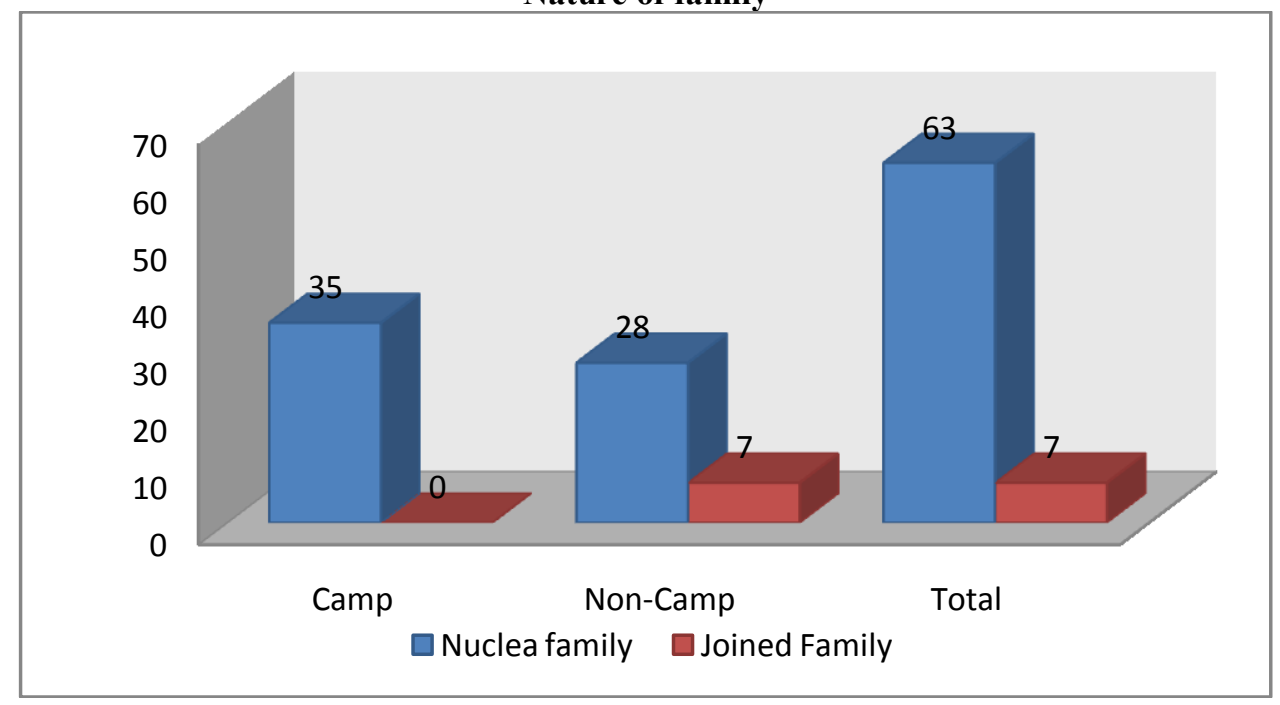




\section{Size of family of the households}

The nature and size of family explain the social, economic and political prospects of any society. The family structure of Kashmiri pandit migrants is mostly economy oriented. However, as civilization progressed, the idea of individualism prompted nuclear families. Urbanization, industrialisation and education support small families to large extent. Population influx and migration to cities are also contributing factors in reducing the family size. Traditional Indian society is characterised by joint family system. However, the changing conditions have compelled the people to go for nuclear families. Same is the case with the pandit's migrant families.

Table 1.5

Source: Survey data

Size of family
\begin{tabular}{|l|l|l|l|}
\hline $\begin{array}{l}\text { Family size (in } \\
\text { number) }\end{array}$ & $\begin{array}{l}\text { Camps } \\
\text { (Nagrota) }\end{array}$ & $\begin{array}{l}\text { Non-Camp } \\
\text { (Durga Nagar) }\end{array}$ & Grand Total \\
\hline $1-5$ & $35(100)$ & $28(80)$ & $63(90)$ \\
\hline $5-10$ & $0(0)$ & $7(20)$ & $7(10)$ \\
\hline $10-15$ & $0(0)$ & $0(0)$ & $0 \quad(0)$ \\
\hline Total & $35(100)$ & $35(100)$ & $70(100)$ \\
\hline
\end{tabular}

(Figures within brackets show the percentages with respect to total)

As far as the size of family is concerned it is evident from the table 1.5, that out of total households in the study area, 90 per cent respondents have family size of 1-5 members, 10 per cent households in between 5-10 members in the study area.

In camp area (Nagrota), 100 per cent households were with a family size of 1-5 members. In non-camp area (Durga Nagar) 80 per cent of households were with a family size of 1-5 family members and 20 per cent households were having a family size of 6-10 family members.

Types of Houses

Types of houses with civic amenities are an indicator of quality of life of the people.

Table.1.6

Types of Houses

\begin{tabular}{|l|l|l|l|}
\hline Types of Houses & $\begin{array}{l}\text { Camp } \\
\text { (Nagrota) }\end{array}$ & Non-Camp (Durga Nagar) & Grand Total \\
\hline Semi-Pacca & $26(74.28)$ & $8(22.85)$ & $34(48.57)$ \\
\hline Pacca & $9(25.71)$ & $27(77.14)$ & $36(51.42)$ \\
\hline Total & $35(100)$ & $35(100)$ & $70(100)$ \\
\hline
\end{tabular}

Source: Survey Data

(Figures within brackets show the percentage with respect to total households)

Table 1.6, shows that out of total households in the study area, about 51.42 per cent are living in pacca houses, 48.57 per cent are living in semi-pacca houses and no body was found living in kacha houses.

In camp (Nagrota) 25.71 per cent households have been living in pacca houses and 74.28 per cent living in semi-pacca houses. On the other hand, in non-camp area 77.14 per cent respondents are living in pacca houses and remaining 22.85 per cent are living in semi-pacca houses in Jammu District. Majority of migrants in camp area have to live in semi-pacca houses with steel teen roof at the top. During summer they suffer a lot from heat and during winter from cold wave. During rainy season there is leakage of roofs at their top, as a result of which life become miserable.

\section{Number of rooms occupied by the households}

Socio-living status of a family can also be measured by the number and conditions of rooms in the house in which the family lives in.

Table.1.7

Number of rooms occupied by the households

\begin{tabular}{|l|l|l|l|}
\hline Number of Rooms & Camp & Non-Camp & Grand total \\
\hline 1 & $35(100)$ & $2 \quad(5.71)$ & $37(52.85)$ \\
\hline 2 & $0(0)$ & $8(22.85)$ & $8(11.42)$ \\
\hline 2 above & $0(0)$ & $25(71.42)$ & $25(35.71)$ \\
\hline Total & $35(100)$ & $35(100)$ & $70(100)$ \\
\hline
\end{tabular}

Source: Survey data

(Figure within brackets show the percentage with respect to total)

Table 1.7 explains that out of total households in the study area, 35.71 per cent households have more than two rooms, 11.42 per cent households have two rooms. 52.85 per cent households have only one room in their houses. In camp area (Nagrota) 100 per cent of the households were found to have one room. In non-camp 
(Durga Nagar), out of total households, 71.42 per cent households have more than two rooms in their houses, 22.85 per cent have two rooms and 5.71 per cent households have only one room in their houses. Because of forced migration these households are compelled to live in a single room in camp area with poor hygienic conditions and in difficult circumstances. This implies that still these households are not having houses with good living conditions which adversely affects the education of the children especially those who have single room in their houses. Since all the activities are done in the same room, children are unable to concentrate fully on their studies. Moreover there is no privacy \& the adequate space for a family in a single room.

\section{Availability of electricityand E- metering}

Availability of electricity is also an important indicator for the socio-economic progress of the region in general and of the household in particular.

Table.1.8.

Availability of Electricity and E- metering

\begin{tabular}{|l|l|l|l|l|l|l|}
\hline \multirow{2}{*}{} & \multicolumn{3}{|c|}{$\begin{array}{l}\text { Camp } \\
\text { (Nagrota) }\end{array}$} & \multicolumn{4}{c|}{$\begin{array}{c}\text { Non-Camp } \\
\text { (Durga Nagar) }\end{array}$} \\
\cline { 2 - 8 } & $\begin{array}{l}\text { Availability of } \\
\text { electricity }\end{array}$ & E- metering & Total & $\begin{array}{l}\text { Availability of } \\
\text { electricity }\end{array}$ & E- metering & Grand Total \\
\hline Yes & $35(100)$ & $35(100)$ & $70(100)$ & $35(100)$ & $29(82.85)$ & $64(91.42)$ \\
\hline No & $0(0)$ & $0(0)$ & $0(0)$ & 0 & $6(17.14)$ & $6(8.57)$ \\
\hline Total & $35(100)$ & $35(100)$ & $70(100)$ & $35(100)$ & $35(100)$ & $70(100)$ \\
\hline
\end{tabular}

Source: Survey data

(Figure within brackets show the percentage with respect to total households)

Table 1.8, shows that 100 per cent households in camp area are electrified and have E-metering, whereas in non-camp area 100 per cent households are electrified but only 82.85 per cent have E-metering and 17.14 per cent are unmetered.

However, electricity cuts are commonly observed in camp as well as in non-camp areas under study. The usual duration of cuts ranges from 6 to 8 hours per day but during peak season particularly in hot summers and cold winters, electricity cuts are further increased to, more than 10-12 hours per day. Sometimes they have to live without electricity.Problems of single phase is also very common in the study area. This clearly implies that though electricity facility is available to all the households but still they suffer a lot due to frequent light cuts \&availability of light on single phase. Thus they find sometimes themselves helpless because dependence on electricity has been increasing day by day not for comfort only but also for earning their livelihood. The poor availability of electricity also affects the health and education of the children's of the households under study. Domestic Chorus also suffers due to poor availability of electricity supply. During summers these households had to go for sleepless nights because of mosquito's flies and rising temperature.

\section{Availability of Drinking Water/Latrine facility/Sanitation Facility}

Source of drinking water: The human settlement in different regions of the world is principally based upon the factors such as the easy availability of safe drinking water and others civic amenities.

Table.1.9

Availability of Drinking Water/Latrine facility/Sanitation Facility in the study area

\begin{tabular}{|c|c|c|c|}
\hline Facilities available & Camp (Nagrota) & $\begin{array}{l}\text { Non-Camp } \\
\text { (Durga Nagar) }\end{array}$ & Grand Total \\
\hline \multicolumn{4}{|c|}{ Drinking Water facility } \\
\hline Hand Pumps & $10(28.57)$ & $\begin{array}{ll}14(40) \\
\end{array}$ & $24 \quad(34.28)$ \\
\hline Tap Water & $20(57.14)$ & $18 \quad(51.42)$ & $38 \quad(54.28)$ \\
\hline Others & $5(14.28)$ & $\begin{array}{ll}3 & (8.57)\end{array}$ & $\begin{array}{ll}8 & (11.42)\end{array}$ \\
\hline Total & $35 \quad(100)$ & $35 \quad(100)$ & $\begin{array}{ll}70 & (100) \\
\end{array}$ \\
\hline \multicolumn{4}{|l|}{ Latrine facilities } \\
\hline Yes & $35 \quad(100)$ & $31 \quad(88.57)$ & $66(94.28)$ \\
\hline No & $\begin{array}{ll}0 & (0) \\
\end{array}$ & $\begin{array}{ll}4 & (11.42) \\
\end{array}$ & $4 \quad(5.71)$ \\
\hline Total & $\begin{array}{ll}35 & (100) \\
\end{array}$ & $\begin{array}{ll}35 & (100) \\
\end{array}$ & $\begin{array}{ll}70 & (100) \\
\end{array}$ \\
\hline \multicolumn{4}{|l|}{ Sanitation Facilities } \\
\hline Yes & $35(100)$ & $29 \quad(82.85)$ & $64(91.42)$ \\
\hline No & $\begin{array}{ll}0 & (0)\end{array}$ & $\begin{array}{ll}6 & (17.14)\end{array}$ & $\begin{array}{ll}6 & (8.57) \\
\end{array}$ \\
\hline Total & $35(100)$ & $\begin{array}{ll}35 & (100) \\
\end{array}$ & $\begin{array}{ll}70 & (100) \\
\end{array}$ \\
\hline
\end{tabular}

Source: Survey data

(Figure within brackets shows the percentage with respect to total) 
Table 1.9 shows that of the total households, 34.28 per cent respondents are getting water from hand pumps and 54.28 per cent are getting tap water, 11.42 per cent households are getting water from other sources such as tank water from tube well in the study area.

In Nagrota camp 57.14 per cent respondents are having tap water and 28.57 per cent are getting water from hand pumps, 14.28 per cent get water from other sources such as tube well and water through PHE tank supply. In non-camp area, 40 per cent respondents are getting water from hand pumps, 51.42 per cent get tap water and 8.57 per cent respondents are getting water from other sources. Thus the main source of water to these households in camp and non-camp area is tap water followed by hand pumps and 11.42 per cent of households were using water from other sources. When asked whether it is safe for drinking 60 per cent of the respondents stated yes. Whereas 40 per cent were unable to say it as safe for drinking purpose. Apart from this the supply of water is not regular during summers.

In non-camp (Durga Nagar) the households stated that though they have different sources of water but the water supply is not regular and it is twice in a week that too of one hour with no fix timing. They have to spent and suffer a lot, for getting water through PHE water tank supply. Household's chorus and day to day activities are being disturbed because of lack of water.

\section{Availability Of Latrine Facilities}

Health is an important asset for the individual as well as community. Good health is a reflection of hygienic condition of an individual. Hygienic practice of person and his family is shaped by the socio-cultural, economic physical condition of the environment and also by the knowledge or awareness of various diseases being spread (park, 2007).Availability of latrine facility is an important indicator in this context. It is seen in the table 1.9, that out of total households in the study area only 94.28 per cent have latrine facility at their homes and 5.71 per cent have to go outside for latrine, which further adds to health problems of these households. Moreover, women's and girls have to face a number of problems when they have to go in open space for attending the natural call

In camp (Nagrota) entire households have latrine facility at their houses whereas, In non-camp (Durga Nagar) 88.57 per cent migrated families have latrine facilities at their houses and remaining 11.42 per cent households have no latrine facility in their houses and have to go outside for it.

\section{Sanitation Facility}

Table 1.9. Shows the availability of sanitation facility. Out of total households in the study area, 91.42 per cent respondents have the sanitation facility and 8.57 per cent respondents have no sanitation facility at the residing place.

In camp area entire households have sanitation facility. While in non-camp area 82.85 per cent respondents have the sanitation facility and remaining 17.14 per cent have no the sanitation facility in the non-camp area.Lack of sanitation facility, further leads to breeding of a numbers of diseases thereby effecting health, health expenditure and performance of the households members.

\section{Spoken Language of the households}

Table. 1.10

Spoken Language of the households

\begin{tabular}{|l|l|l|l|}
\hline Languages (spoken) & $\begin{array}{l}\text { Camp } \\
\text { (Nagrota) }\end{array}$ & $\begin{array}{l}\text { Non-Camp (Durga } \\
\text { Nagar) }\end{array}$ & Grand Total \\
\hline Kashmiri & $25(71.42)$ & $23(65.71)$ & $48(68.57)$ \\
\hline Hindi & $10(28.57)$ & $3 \quad(8.57)$ & $13 \quad(18.57)$ \\
\hline Both (Hindi \& Kashmiri) & $0(0)$ & $9(25.71)$ & $9(12.85)$ \\
\hline Total & $35(100)$ & $35(100)$ & $70(100)$ \\
\hline
\end{tabular}

Source: Survey data

(Figures within brackets shows the percentage rate with respect to total languages used by respondents)

Table 1.10 shows the different languages are used by the migrated Kashmiri pundits at their native palace as given detail in above table.

In camp area (Nagrota) 71.42 and 28.57 per cent migrated Kashmiri families were using Kashmiri and Hindi as their language and in non-camp area 65.71, 8.57 and 25.71 per cent were using Kashmiri, Hindi and other languages as a means of communication. The capability of these respondents in using different languages has shown considerable improvement, which is evident from the fluency of their languages and no body was found speaking Urdu. 


\section{Celebration Of Festivals By The Households}

Table.1.11,

Celebration of festivals by the households

\begin{tabular}{|l|l|l|l|}
\hline $\begin{array}{l}\text { Festival } \\
\text { Celebration }\end{array}$ & $\begin{array}{l}\text { Camp } \\
\text { (Nagrota) }\end{array}$ & $\begin{array}{l}\text { Non-Camp } \\
\text { (Durga Nagar) }\end{array}$ & Grand Total \\
\hline Kashmiri & $26(74.28)$ & $20(57.14)$ & $46(65.71)$ \\
\hline Local & $0(0)$ & $2 \quad(5.71)$ & $2 \quad(2.85)$ \\
\hline Both & $9(25.71)$ & $13(37.14)$ & $22(31.42)$ \\
\hline Total & $35(100)$ & $35(100)$ & $70(100)$ \\
\hline
\end{tabular}

Source: Survey data

(Figures within brackets percentage mentioned with respect to total amount)

Migrated Kashmiri pandits, celebrate festivals at their residing place by different ways. Celebrations of festivals by respondents are elucidated in the above given table.

Out of total households, 65.71 per cent households do celebrate their festivals on the basis of Kashmiri traditions at their present residing place.31.42 per cent celebrate their festivals on the basis of both Kashmiri as well as local culture, Whereas 2.85 per cent households celebrate their festivals on the local culture basis.

In camp area (Nagrota), 74.28 per cent household celebrate their festivals on the basis of Kashmiri culture, whereas 25.71 per cent celebrate by both the cultures Kashmiri as well as local etc,. In non-camp (Durga Nagar area) 57.14 per cent households celebrate their festivals on the basis of Kashmiri traditions inherited by them at their native place whereas 37.14 per cent households celebrate their festivals at both, Kashmiri as well as on the basis of local culture, whereas 5.71 per cent households celebrate their festivals only on the local culture basis. According to the majority of the households most important festival of them is (Herat in Kashmiri) Shivratri. It is celebrated at large scale by them and after Shivratri wet walnuts are sent to their closed relatives and friends both in J\&K and to other states. Young children enjoy all the festivals be it deepawali, Holi, Bisakhi, Janamashtmi etc., thus local culture has its impact on these households and it is relatively more in non-camp households than in camp households because these households have relatively more interaction with the locals than of camp households.

\section{References}

[1]. Agozino (2000). “Theoretical and Methodological Issues in Migration Research.”London: Ashgate Publishing.

[2]. Cohen, R. \& Deng, M. (1998). 'Masses in plight: the Global Crisis of Internal Displacement.' Washington D.C: Brookings institution Press.

[3]. Kalla, A. K. (1995). 'Kashmiri Pandits and their Diversity.' Delhi: B.R. Publisher Corporation.

[4]. Koul, A. (1991). 'The Kashmir Pandits'. Delhi: Utpal Publication.

[5]. Koul, S. (1992). 'Freedom Struggle in Jammu \& Kashmir'. New Delhi: Anmol Publication.

[6]. Kumar, D. P. (1996). 'Kahmir Return to Democracy’. New Delhi: Cosmo Publications.

[7]. Revinder, K. (2005). Migration and society. New Delhi, Rawat Publication, 41-52.

[8]. Soondas, A. (2012). THE TIMES OF INDIA, 1.

[9]. Verma, P.S. (1994). Jammu and Kashmir at Political Crossroad New Delhi: Vikas publishing house,29-36.

[10]. Wasim, K., (2008). 'Migration of Kashmir pandits: Kashmiriyat challenged,' Indian Journal of political science.

[11]. Wood, (1994). Forced migration: Local conflict and International Dilemmas.

[12]. Zutshi, (2003). Status of Widow of Kashmir: The Displaced Population, In Living Death: Trauma of Widowhood in India. V.M. Giri. (Eds.) Gayn Publications, New Delhi. 